\author{
Matylda Pachowicz \\ Wyższa Szkoła Pedagogiki i Administracji im. Mieszka I w Poznaniu \\ E-MAIL: matylda.pachowicz@wp.pl oRCID: oooo-ooo1-9326-6411
}

\title{
Edukacja i terapia osób z niepełnosprawnością w czasie pandemii COVID-19 na przykładzie Ośrodka Rewalidacyjno-Edukacyjno-Wychowawczego
}

\section{STRESZCZENIE}

Czas zamknięcia szkół i placówek oświatowych w czasie pandemii COVID-19 odsłonił istniejące nierówności społeczne pod względem dostępu do usług edukacyjnych i terapeutycznych w Polsce. Wprowadzenie obowiązkowego nauczania na odległość spowodowało, iż znaczna liczba uczniów (pochodzących z ubogich obszarów lub domów) ma utrudniony dostęp do nauki ze względu na ograniczone możliwości korzystania z nowych technologii oraz Internetu. W szczególnie trudnej sytuacji są osoby o specjalnych potrzebach rozwojowych i edukacyjnych oraz ich rodziny ${ }^{1}$. Wiele z tych rodzin jest w niekorzystnej sytuacji ekonomicznej ze względu na duże koszty, jakie ponoszą na rehabilitację i różne terapie.

W niniejszym artykule została opisana edukacja specjalna i terapia na odległość w czasach pandemii COVID-19 oraz po powtórnym uruchomieniu zajęć rewalidacyjno-wychowawczych w maju 2020 roku. Wyeksponowana została perspektywa nauczycieli, terapeutów oraz specjalistów pracujących w Ośrodku RewalidacyjnoEdukacyjno-Wychowawczym. W artykule zostały zaprezentowane dane zebrane na podstawie wywiadu przeprowadzonego w trakcie zamknięcia ośrodka oraz po powtórnym uruchomieniu w nim zajęć specjalistycznych Wykorzystane zostały więc metody badawcze o charakterze jakościowym, które pozwoliły zarysować perspektywę mikro².

SŁOWA KLUCzOWE: pandemia, edukacja specjalna, zdalne nauczanie, dziecko o specjalnych potrzebach rozwojowych i edukacyjnych, terapia, niepełnosprawność, pomoc psychologiczno-pedagogiczna, rehabilitacja

1 Szerzej zjawisko nierówności cyfrowych zostało opisane w tekście P. Plichta (2020). Autor zaznacza, iż ,jeśli nierówności w partycypacji społecznej młodych osób z niepełnosprawnościami nie zostaną ograniczone, retoryka edukacji włączającej będzie tylko sloganem" (tamże, s. 71). Zob. Humphrey, Hebron (2014, s. 1-8).

2 W ramach badań jakościowych zostały przeprowadzone dwa wywiady telefoniczne: jeden 15 maja 2020 roku, w czasie zamknięcia ośrodka i realizacji zajęć wyłącznie w formie zdalnej; drugi wywiad kilka dni po ponownym uruchomieniu zajęć rewalidacyjno-wychowawczych w ośrodku, 4 czerwca 2020 roku. Zastosowanym narzędziem był scenariusz wywiadu częściowo ustrukturyzowanego. 
Więź

tworzy się w czasie, który sobie nawzajem dajemy

(Längle, 2019, s. 160)

\section{Wprowadzenie}

W niniejszym artykule została zarysowana perspektywa „wewnętrzna” (Flick, 2011, s. 13) przez analizę doświadczeń pedagoga specjalnego - terapeuty³ który w czasie pandemii stanął przed koniecznością reorganizacji swojego sposobu pracy z osobami z niepełnosprawnością. Wyłonione zostały następujące kategorie znaczące, by opisać i wyjaśnić ważne zagadnienia społeczne związane z jakością rehabilitacji oraz edukacji specjalnej w Polsce w czasie pandemii:

- warsztat pracy pedagoga specjalnego;

- priorytety edukacji specjalnej i terapii w formie zdalnej;

- sieć wsparcia dla rodziny dziecka z niepełnosprawnością.

Ze względu na to, iż w badaniach jakościowych nie formułuje się na wstępie dokładnej definicji przedmiotu badawczego oraz hipotez, natomiast „dużą wagę przykłada się do kontekstu i konkretnych przypadków jako czynników tłumaczących badane zagadnienie" (Flick, 2011, s. 14), postawione zostały następujące pytania badawcze (zob. Flick, 2012, s. 51-53):

- Jakie zmiany dokonały się w ramach warsztatu pracy pedagoga specjalnego w związku z koniecznością pracy zdalnej?

- Co stanowi fundament piramidy priorytetów edukacji specjalnej i terapii w formie zdalnej?

- Jakie możliwości i ograniczenia dostrzegają pedagodzy specjalni w budowaniu relacji terapeutycznej za pomocą komunikacji zapośredniczonej?

- W jaki sposób można budować sieć wsparcia dla rodziny dziecka z niepełnosprawnością $\mathrm{w}$ trudnych warunkach izolacji oraz różnorakich ograniczeń spowodowanych pandemią?

Problemy edukacji i terapii osób z niepełnosprawnością w czasie pandemii COVID-19 zostały przedstawione na przykładzie niepublicznego Ośrodka

3 Osoba udzielająca wywiadów ukończyła dwa kierunki studiów: Pedagogikę specjalną (w specjalności oligofrenopedagogika z terapią autyzmu) oraz Edukację elementarną z terapią pedagogiczną. Jej staż pracy w opisywanym ośrodku w roli wychowawcy w klasie "Przysposabiającej do pracy” oraz w roli terapeuty wynosi dwa lata. Wcześniej osoba ta pracowała przez siedem lat w Specjalnym Ośrodku Szkolno-Wychowawczym. 
Rewalidacyjno-Edukacyjno-Wychowawczego. Ośrodek znajduje się w mieście średniej wielkości, a swoją ofertę kieruje do osób w różnym wieku i z różnymi niepełnosprawnościami (m.in. z mózgowym porażeniem mózgowym, $\mathrm{z}$ autyzmem, $\mathrm{z}$ niepełnosprawnością wzrokową oraz słuchową, sprzężoną oraz głęboką). Obecnie uczęszcza do niego 45 podopiecznych (łączna liczba osób $\mathrm{z}$ kadry jest nieco większa). W ramach działań ośrodka realizowane są zajęcia rewalidacyjno-wychowawcze (RW), przysposabiające do pracy oraz zajęcia korekcyjno-kompensacyjne (indywidualne). Nowością jest projekt z PFRON-u dla osób, które ukończyły 25 lat. Uczestnicy mają okazję uczestniczyć w zajęciach kulinarnych, muzycznych oraz z zakresu stolarstwa. Dodatkowo organizowane są cykliczne zajęcia prowadzone przez osoby spoza ośrodka związane z teatrem, czytelnictwem, doświadczeniami chemicznymi. Dla niektórych podopiecznych atrakcję stanowią zajęcia z dogoterapii. Ważną część działań terapeutycznych stanowi trening umiejętności społecznych realizowany w naturalnych sytuacjach społecznych, chociażby podczas wyjść do sklepu, do kawiarni czy na zewnętrzną siłownię.

Nagła sytuacja pandemii i konieczność zamknięcia na kilka tygodni ośrodka spowodowała znaczne ograniczenia w realizacji zajęć rewalidacyjnych oraz edukacyjnych, które w tym czasie mogły być realizowane tylko $\mathrm{w}$ formie zdalnej. Sytuacja ta stanowiła ogromne wyzwanie zarówno dla dyrekcji ośrodka, pracujących w nim terapeutów i specjalistów oraz rodziców. Wszyscy stanęli przed koniecznością reorganizacji swojego sposobu pracy, co wiązało się również ze zmianami w codziennym funkcjonowaniu. Terapeutka udzielająca wywiadu w następujący sposób opisuje początki pracy zdalnej:

\footnotetext{
Myślę, że dla wszystkich to był szok. Zresztą, jeśli chodzi o moją osobę to ja zawsze powtarzam, że lubię ludzi i kontakt osobisty, więc brakuje mi podopiecznych i pracowników. No wszystkich mi brakuje, bo lubię swoją pracę, więc musiałam się strasznie przestawić na pracę zdalną, czyli komputer. (...) Z dnia na dzień się wszystko się pozmieniało, wcześniej miałam pomysł w głowie i układałam sobie plan, co i gdzie kupić, co mam już w szafce w pracy. A tutaj praca na pewno jest trudniejsza, ponieważ w domu podopieczni nie mają też tego (kart pracy, materiałów albo środków, których ja używam), i trzeba się było opierać na tym, co mają w domu. Dowiadywałam się o tym z wywiadów z rodzicami. Jeden z moich podopiecznych jest niewidomy, ma zaburzone czucie głębokie i słabe ręce, więc szukałam inspiracji, co może mieć w domu, w kuchni, żeby pobudzić wszystkie zmysły (typu dotyk, węch).
}

\section{Edukacja i terapia osób z niepełnosprawnością w czasie pandemii}

Realizowanie edukacji w formie zdalnej stanowiło duże wyzwanie dla wszystkich nauczycieli, jednak w szczególnie trudnej sytuacji zostali postawieni 
pedagodzy specjalni oraz specjaliści. Fundamentem pracy z osobami z niepełnosprawnością jest bowiem kontakt osobisty, praca $\mathrm{z}$ ciałem i pobudzanie wszystkich zmysłów (stymulacja polisensoryczna) ${ }^{4}$. Duże znaczenie ma budowanie relacji między terapeutą a podopiecznym, gdyż ona właśnie często stanowi klucz do sukcesu terapeutycznego. Kiedy więc nastała konieczność pracy zdalnej, terapeuci zostali pozbawieni wielu możliwości budowania kontaktu z podopiecznymi, a realizacja zajęć edukacyjnych spadła w dużej mierze na rodziców. Oto jak wyglądała codzienna organizacja zajęć zdalnych:

Dużo godzin spędzam przy komputerze. Od rana siadam na godzinę, żeby ogarnąć wysyłanie materiałów przygotowanych dzień wcześniej. Zaczynam od planu tygodniowego (ponieważ pracujemy według ośrodków pracy), zawsze jest tydzień $\mathrm{z}$ góry przygotowany tematycznie. Teraz $\mathrm{w}$ zdalnej edukacji już musiałam mieć w głowie obraz, co ja mogę znaleźć w domu czy w internecie i jak to dostosuję do tej sytuacji. Wcześniej to było prostsze, bo każdy temat mogłam realnie spełnić, mogłam coś przywieść, ukopać ziemi w ogródku, np. na zajęcia z sadzenia kwiatów. A teraz jest to o wiele trudniejsze.

Praca w formie zdalnej stanowi nie lada wyzwanie, szczególnie jeśli wcześniej nie korzystało się z nowych technologii. Sytuacja pandemii spowodowała, że $\mathrm{z}$ dnia na dzień trzeba było diametralnie zmienić sposób pracy oraz formy kontaktu $\mathrm{z}$ innymi. Tym trudniejsze było to zadanie, im bardziej praca opierała się na bezpośrednim kontakcie w klientem, pacjentem czy podopiecznym. Podstawowym założeniem koncepcji edukacji zdalnej powinien być brak wykluczenia. Wypracowane modele pracy nie powinny więc mieć charakteru dyskryminującego, chociażby ze względu na posiadany w domu sprzęt oraz jego ilość. Modele te powinny być dostosowane do specjalnych potrzeb rozwojowych i edukacyjnych uczniów i uwzględniać ich dobrostan, również w zakresie zrównoważonego czasu korzystania z technologii (Tarkowski z zesp., 2020, s. 3).

Warty podkreślenia jest trud, jaki włożyli nauczyciele, terapeuci oraz specjaliści, by choć w ograniczonym stopniu realizować zadania wpisane w ich zawód. Przysłuchując się relacji wielu z nich, można dostrzec u nich objawy zmęczenia i tzw. technostresu, wynikającego z presji szybkiego opanowania nowych technologii, wielogodzinnych poszukiwań materiałów w internecie oraz prób zbudowania i utrzymania kontaktu za pomocą komunikacji zapośredniczonej (przez komputer lub nowe media). Pedagog specjalny udzielający wywiadu wypracował sobie następujący system pracy:

4 Zob. A. Kułaga (2020, roz. 4, s. 83-93). Niniejszy rozdział zawiera opis nauczania zdalnego uczniów z niepełnosprawnością intelektualną w stopniu umiarkowanym uczęszczających na zajęcia w Specjalnym Ośrodku Szkolno-Wychowawczym. 
Czasami siadam w weekendy, żeby przygotować materiały na następny tydzień. Jak jestem wyrobiona w domu to siadam w dzień powszedni tak o 9:0o (trzy godziny pracy), i po południu podobnie. To zależy, ale ja staram się to robić w miarę możliwości regularnie, średnio sześć godzin przeznaczam na wyszukanie materiałów i stworzenie czegoś na pięć dni wprzód. Dla każdego podopiecznego muszę przygotować coś odrębnego. Ale oprócz tego mam jeszcze telefony różne, wideokonferencje, i to cały praktycznie dzień mi zabiera. Trochę od rana, trochę w południe i po południu, a jeszcze czasami wieczorem. Myślę, że praca zdalna jest trudniejsza dla mnie, bo normalnie jak idę do pracy, to przygotowuję się $\mathrm{z}$ dnia na dzień, mam już coś przygotowane i jest mi fajniej, łatwiej, mam wtedy „szerszy umysł”.

Fundamentem pracy zdalnej okazała się ścisła współpraca terapeuty z rodzicem. W omawianym ośrodku dużą wagę postawiono więc na budowanie sieci wsparcia dla rodziców. Bardzo pomocne okazały się częste rozmowy telefoniczne (np. o zdrowiu, co im sprawia trudność, czy potrzebna jest dodatkowa pomoc np. przy zrobieniu zakupów, czy potrzebny jest dodatkowy sprzęt). Został włączony taki system, że jeśli w danym domu brakowało drukarki, to materiały wysyłane były pocztą lub użyczano drukarkę na określony czas. Oprócz rozmów telefonicznych, które często stanowiły podstawową formę wsparcia psychicznego, terapeuci organizowali wideokonferencje w grupach wyżej funkcjonujących (1-2 razy w tygodniu). Ich głównym celem było nie tyle przeprowadzenie konkretnych zajęć, ile wsparcie rodziców i utrzymanie kontaktu z podopiecznymi, co spotykało się z ogromną radością z ich strony, gdyż bardzo tęsknili za zajęciami w ośrodku. Groźnym zjawiskiem, które można było zaobserwować w czasie pandemii było pojawienie się lub zwiększenie zachowań trudnych u dzieci i młodzieży z niepełnosprawnością (takich jak agresja czy autoagresja), a w niektórych przypadkach wyraźny regres w rozwoju.

W szczególnie trudnej sytuacji znalazły się osoby z autyzmem, dla których rytuały codzienne są bardzo ważne w kontekście odczuwanego poczucia bezpieczeństwa5 ${ }^{5}$. Jedna $\mathrm{z}$ rodzin $\mathrm{z}$ dzieckiem $\mathrm{z}$ autyzmem, które uczęszcza do omawianego ośrodka, zaobserwowała u swojego dziecka zachowania autoagresywne i agresywne, które wcześniej się w ogóle nie pojawiały. Czytając fora dyskusyjne dla rodziców można dojść do wniosku, że nie jest to sytuacja odosobniona. W najcięższym położeniu były te rodziny wtedy, gdy nie można było wychodzić $\mathrm{z}$ domu i korzystać $\mathrm{z}$ dobrodziejstw przyrody (nawet spacer do pobliskiego parku czy lasu był zakazany), wtedy zachowania trudne były najbardziej nasilone. Niestety, czasowe obostrzenia spowodowały taką

Podobne wnioski można odnaleźć w A. Kułaga (2020, s. 87). 
kumulację stresu, że zachowania autoagresywne i agresywne utrzymują się u dzieci z niepełnosprawnością pomimo tego, że można już bardziej swobodnie się poruszać na zewnątrz. W opisywanej rodzinie, chłopiec $\mathrm{z}$ autyzmem dodatkowo odmawia teraz wykonywania przesyłanych zadań (a na początku edukacji zdalnej wykonywał wszystko chętnie).

$Z$ relacji terapeuty wynika, iż nowa sytuacja edukacyjna, w jakiej znaleźli się wszyscy uczestnicy szczególnie dotknęła osoby $\mathrm{z}$ autyzmem, ponieważ z tym zaburzeniem rozwojowym wiąże się silne przywiązanie do pewnych schematów oraz do rutyny, a wszelkie nowości odbierane są w kategoriach zagrożenia i utraty poczucia bezpieczeństwa. Przykładem może być drugi przypadek chłopca $\mathrm{z}$ autyzmem (w wieku 12-13 lat) - u niego pojawił się regres związany z czynnościami samoobsługowymi. Wcześniej nigdy nie miał on problemów w tym zakresie (czynności fizjologiczne opanował prawidłowo). Na początku edukacji zdalnej też jeszcze nie było problemów w tym obszarze. Dopiero z czasem mama zaczęła zgłaszać wychowawcy, że "coś się dzieje i nie idzie w tę stronę, w którą powinno iść", chłopiec przestał bowiem kontrolować potrzeby fizjologiczne. Na wszystko nałożyła się jeszcze trudna sytuacja rodzinna tego podopiecznego. Powyższe przykłady stanowią tylko zarys szerszego obrazu trudności, z jakimi zmagają się cały czas (od momentu ogłoszenia pandemii) rodzice dzieci z niepełnosprawnością. Terapeutka biorąca udział w badaniach jakościowych nakreśliła to następująco:

Ta edukacja zdalna to mega utrudnienie dla osób niepełnosprawnych, oni w ośrodku fajnie funkcjonują, w domu niekoniecznie. Jedna $\mathrm{z}$ mam się żaliła, że jej dziecko nie chce w domu wykonywać zadań, nie ma więc mowy o żadnej pracy w domu. Inna mama nie ma kiedy, bo pracuje, i dziecko jest zostawione z babcią, która też ma swoje zajęcia. Staram się przede wszystkim wspierać i to jest dla nas priorytetem. Zresztą my zawsze byliśmy skupieniu na wsparciu rodziców i podopiecznych. Ale niekoniecznie skupia się to na tej nauce, bo to jest tak dla nich trudna sytuacja, są też matki samotnie wychowujące, samo wyjście po zakupy było dla nich wyczynem lub po prostu niemożliwe.

Ze względu na ogromne potrzeby rodziców, w omawianym ośrodku została wzmocniona rola psychologa, który ma stały kontakt $\mathrm{z}$ rodzicami, poprzez wideokonferencje oraz rozmowy telefoniczne (ma wyznaczone godziny w ciągu dnia, od godziny 8:0o), a rodzice bardzo często korzystają z takiej możliwości. Okazuje się, że większość z nich woli rozmawiać przez telefon niż spotykać się w ramach wideokonferencji, gdyż ta forma stanowi dla nich większy dyskomfort. W sytuacji, gdy rodzinom dzieci z niepełnosprawnością doszły dodatkowe obciążenia związane z edukacją i terapią zdalną, jak również ograniczone zostały możliwości zaspokajania codziennych potrzeb, 
wiele ośrodków i placówek postawiła na budowanie sieci wsparcia dla rodziców. Tym samym realizowanie zajęć edukacyjnych i rewalidacyjnych zeszło na plan dalszy. Przykładem takiego podejścia jest omawiany ośrodek:

Ale u nas staramy się nie wywierać presji na rodzicach w kwestii robienia zadań w domu. U nas rodzice starają się w miarę możliwości (kulinarne czy stolarskie w ograniczonym zakresie). Natomiast jeśli chodzi o specjalistyczne zajęcia, np. z integracji sensorycznej, koleżanka częściowo korzysta z linków do materiałów, które można obejrzeć albo odsłuchać, ale też ona sama się nagrywa i mówi, że $\mathrm{w}$ domu jest wtedy bałagan, albo dzwoni i jest na kamerze i kontaktuje się z podopiecznych. Ale nie zawsze podopieczny chce, np. „nie ma dzisiaj ochoty, bo nie czuje się dobrze”. Ale można porozmawiać wtedy, nie trzeba na siłę wykonywać jakiś ćwiczeń. Myślę, że to też jest bardzo ważna rzecz.

Czas pandemii wiele zmienił nie tylko w sferze zawodowej, ale również prywatnej. Nawet najbardziej zagorzali przeciwnicy nowych technologii, musieli sięgnąć po nowe rozwiązania, by móc pracować zdalnie. Szczególnie widoczna, spektakularna przemiana sposobu pracy dokonała się w grupie nauczycieli i terapeutów, zmuszonych okolicznościami do opanowania nowoczesnych narzędzi do komunikacji. Oto relacja jednego z nich:

Jeśli chodzi o wykluczenie cyfrowe, moim podopiecznym jest osoba niewidoma, więc jeśli chodzi o narzędzia to powinnam pracować tylko na głosie (no bo nie mam innej możliwości w pracy zdalnej), brakuje tego bezpośredniego kontaktu, chociażby aktywizowania zmysłu dotyku. W ogóle przy niepełnosprawnościach intelektualnych jest to trudne. Chociaż jest trochę tych narzędzi. Terapeuci z naszego ośrodka korzystają chociażby z najprostszego Messengera, gdzie jest telefon pod ręką i mama widzi, uczeń widzi i słyszy. To jest najprostsze. A my korzystamy z tego Zooma na wideokonferencjach, który został uruchomiony na prośbę rodziców.

Paradoksalnie, dzięki takim rozwiązaniom poprawił się w niniejszym ośrodku kontakt specjalistów z rodzicami (stał się on częstszy i bardziej otwarty), a wymiana informacji stała się bardziej systematyczna. Terapeuci podkreślają, że rozmowy telefoniczne okazały się dla rodziców mniej krępujące niż spotkania „twarzą w twarz” i dzięki temu chętniej opowiadają o swoich problemach i bolączkach. Zatem na edukację zdalną można spojrzeć z różnych perspektyw, kluczową sprawą okazało się utrzymanie kontaktu z podopiecznym i z jego rodzicami poprzez formy zapośredniczone. Akcent został postawiony na budowanie pozytywnych relacji oraz udzielanie wsparcia emocjonalnego. Wpisuje się to idealnie w opisaną przez J. Pyżalskiego piramidę priorytetów edukacji zdalnej w warunkach izolacji spowodowanej pandemią. Jej fundamentem są relacje z uczniami i rodzicami oraz relacje rówieśnicze. $\mathrm{Na}$ tą 
warstwę nakłada się szeroko rozumiane wsparcie społeczne oraz budowanie odporności (rezyliencji). Na samej górze piramidy priorytetów jest dopiero skuteczna dydaktyka zdalna (Pyżalski, 2020, s. 25-26).

W działaniach omawianego ośrodka komunikacja zapośredniczona obejmuje w największym stopniu wychowawcę grupy wraz z rodzicami ( $w$ przeważającym stopniu $\mathrm{z}$ matkami) dziecka $\mathrm{z}$ niepełnosprawnością. Relacje rówieśnicze $\mathrm{w}$ okresie izolacji społecznej zostały $\mathrm{z}$ wielu przyczyn zmarginalizowane ${ }^{6}$. Efekty działań edukacyjnych oraz rewalidacyjnych $\mathrm{w}$ formie zdalnej zostały więc uzależnione od jakości współpracy, jaka się wytworzyła między rodzicem a specjalistą. W płaszczyźnie relacji nauczyciel - rodzina pojawiają się bowiem cztery kluczowe elementy: ustalenie wspólnych celów (sposobów działania), stała komunikacja oraz otwarty przepływ informacji, i co nie mniej ważne: udzielanie wsparcia sobie nawzajem ${ }^{7}$ Terapeutka pracująca w niniejszym ośrodku opisuje swoje doświadczenia w formie następujących wniosków:

Jeśli chodzi o dzieci niepełnosprawne, to uważam, że edukacja zdalna nie jest dobrą rzeczą, ja jestem na „Nie”. Nawet te wszystkie narzędzia typu Messengery, Zoomy nie, bo to nie jest to. Minusem wielkim jest na pewno dodatkowa praca w sensie dokumentów. A plus, to ja myślę, że jest teraz fajniejszy kontakt z rodzicem. Zapewne ta cała sytuacja spowodowała, że rodzic miał większą potrzebę wygadania się, i chętniej rodzice rozmawiali przez telefon. I przez Messengera też mieli taką potrzebę. W tej sytuacja ważna była współpraca, bo wcześniej każdy swoją pracę wykonywał (był wyraźny podział obowiązków), a teraz bez współpracy nie byłoby żadnej pracy, chociażby zorientowanie się, na czym te dzieci mają w domu pracować, stąd ten kontakt był niezbędny.

\section{Ponowne uruchomienie zajęć rewalidacyjno-wychowawczych w ośrodku}

Powrót terapeutów i innych specjalistów do pracy w ośrodku w drugiej połowie maja wiązał się z wieloma zmianami związanymi chociażby z kwestiami organizacyjnymi. Każdy z nich przeszedł obowiązkowe szkolenie BHP na temat nowych procedur sanitarnych i zaostrzeń w tym obszarze. Zarówno pedagodzy jak i rodzice zobowiązani zostali do wypełnienia ankiety, przed przyjściem do ośrodka. Pytania ankietowe dotyczą kwestii zdrowia, sposo-

6 Podpowiedzi dotyczące pomocnych narzędzi w budowaniu dobrych relacji oraz bezpiecznej i życzliwej atmosfery w klasie w czasie nauczania zdalnego zawiera praca zbiorowa: Budowanie relacji. Materiały do pracy zdalnej z uczennicami i uczniami, która powstała w ramach projektu „Szkoła Przyjazna Prawom Człowieka. Jak przeciwdziałać wykluczeniu i przemocy w szkole?", (Podsiadło-Dacewicz, 2020).

7 Więcej na ten temat w tekście: W. Poleszak, J. Pyżalski (2020). 
bów spędzania kwarantanny oraz kontaktów z innymi w tym czasie. Rodzice otrzymali wytyczne co do stanu zdrowia ich dzieci (objawy wskazujące na jakiś stan chorobowy np. katar, przeziębienie powodowały niemożność przyjęcia dziecka na zajęcia, aż objawy nie ustaną). Zaostrzenia dotyczyły również samej organizacji zajęć, po powrocie każda grupa ma obowiązek „zamykania się" w swojej sali, żeby ograniczyć kontakt między podopiecznymi. Dodatkowo, codziennie jest mierzona temperatura każdemu pracownikowi oraz podopiecznemu i nikt nie ma wstępu do ośrodka z zewnątrz. Na wyposażenie ośrodka składa cały „ekwipunek sanitarny”, jak przyłbice, maseczki, rękawiczki oraz środki dezynfekujące. Terapeutka udzielająca wywiadu w następujący sposób opisuje zmiany:

Po wejściu jest u nas taki korytarzyk, do pierwszych drzwi podjeżdża bus albo przychodzi rodzic, w tych drzwiach otwiera jedna osoba drzwi w masce i w rękawiczkach, przeprowadza przez krótki korytarzyk i zaraz jest w drugich drzwiach mierzona temperatura, jest dezynfekcja rąk. Każdy ma mierzoną temperaturę. (...) Gdzie są największe obawy? Dużo zależy od osoby, od osobowości, od predyspozycji - jedni do czegoś podchodzą spokojnie, a inni panikują. Są więc osoby, które prawie mają natręctwo z dezynfekowaniem rąk non stop. Nie ukrywajmy, że jak dziecko niepełnosprawne kichnie, to nie zakryje ust, więc są osoby, które się tego boją. Takich osób jest może pięć, sześć, z takim bardzo lękowym nastawieniem.

Okazuje się, że zastosowanie się do wszystkich procedur i restrykcji sanitarnych w przypadku specjalnych ośrodków jest niemożliwe albo w dużym stopniu ograniczone, ze względu na specyfikę pracy z osobami z niepełnosprawnością intelektualną. Kwestie problematyczne dotyczące przede wszystkim noszenia maseczek przez podopiecznych i terapeutów:

Nikt $\mathrm{z}$ nas twarzy nie zakrywa, bo dla mnie to jest trudne, jeśli chodzi o dzieci. I męczące jest to, duszące, a maseczka odpada moim zdaniem (nie widać twarzy, dzieciaki boją się, patrzą na nas i są niepewne, kto to jest).

Dodatkowym utrudnieniem dla terapeutów jest podwójny system pracy, bowiem zajęcia przybrały dwie formy: codzienne grupowe zajęcia rewalidacyjno-wychowawcze w ośrodku, a po powrocie do domu nauczanie zdalne. Wszyscy podopieczni nadal są objęci tą formą nauczania, ponieważ w ośrodku nie zostały uruchomione zajęcia edukacyjne. Materiały wysyłane są drogą mailową albo wkładane są do plecaka tym podopiecznym, którzy są w danym dniu w ośrodku. Praca na miejscu została nieco skrócona (zajęcia odbywają się teraz w godzinach od 7:30 do 13:00), i potem jest kontynuowana w domu. Terapeuci podkreślają, że niezwykle ważne okazało się uruchomienie w maju zajęć RW, 
a co za tym idzie stworzenie możliwości bezpośredniej pracy z dziećmi i młodzieżą z niepełnosprawnością. Kilka tygodni wyłącznej pracy zdalnej miało bowiem negatywny wpływ na ich funkcjonowanie, zarówno w sferze fizycznej, jak i psychicznej. Oto spostrzeżenia jednego z terapeutów:

My zresztą widzimy po dzieciach, że dużo „do tyłu poszło”. Jest to nasza taka ogólna refleksja, że dzieci się cofnęły, i to bardzo. My to zauważyłyśmy jako wychowawcy, ale specjaliści, którzy zabierają dzieci do siebie na zajęcia indywidualne, to też przychodzą i za każdym razem mówią, że jest po prostu szok. Wiele rzeczy zanika, chociażby takie proste rzeczy jak dni tygodnia. My to jesteśmy zszokowane. Coś, co było wypracowane, np. takie układanie (co podopieczni już śmigali), to teraz nie potrafią. Widać, że ręce są spięte. A jak się pytamy, to się okazuje, że w domu jednak to nie za bardzo było robione (dzieci to powiedzą, rodzice nie zawsze). Dostawałyśmy zdjęcia i wszystko fajnie, a później okazywało się, że siostra trochę robiła... Widać te zmiany też fizyczne.

W tabeli 1 ukazano zróżnicowanie form pracy oraz form kontaktu terapeutów i specjalistów z podopiecznymi oraz ich rodzicami, w trzech perspektywach czasowych.

Tabela 1. Analiza porównawcza działań edukacyjnych i terapeutycznych w trzech różnych okresach działalności Ośrodka Rewalidacyjno-Edukacyjno-Wychowawczego

\begin{tabular}{|c|c|c|}
\hline Przed pandemią & $\begin{array}{c}\text { W czasie pandemii - } \\
\text { wyłącznie edukacja zdalna } \\
(12.03-17.05)\end{array}$ & $\begin{array}{l}\text { Powrót zajęć RW w ośrodku } \\
\text { (od } 18 \text { maja 2020) }\end{array}$ \\
\hline $\begin{array}{l}\text { Łączone zajęcia (dwie grupy } \\
\text { w jednej sali plus jedna } \\
\text { osoba jako „pomoc”); } \\
\text { Zajęcia są wspólne, ale indy- } \\
\text { widualizacja pracy. }\end{array}$ & $\begin{array}{l}\text { Zajęcia w formie indywi- } \\
\text { dualnej (brak kontaktów } \\
\text { między rówieśnikami). }\end{array}$ & $\begin{array}{l}\text { Specjalne procedury sani- } \\
\text { tarne; } \\
\text { Zajęcia oddzielnie w każdej } \\
\text { grupie }\end{array}$ \\
\hline $\begin{array}{l}\text { Zajęcia RW; przysposobie- } \\
\text { nie do pracy oraz projekt } \\
\text { z PFRON-u (25+); } \\
\text { Dodatkowo zajęcia ko- } \\
\text { rekcyjno-kompensacyjne } \\
\text { (indywidualne). }\end{array}$ & $\begin{array}{l}\text { Wszystkie zajęcia w formie } \\
\text { indywidualnej. }\end{array}$ & $\begin{array}{l}\text { Skrócone zajęcia (podobnie } \\
\text { jak w pandemii nie realizo- } \\
\text { wanie podstawy programo- } \\
\text { wej); } \\
\text { Tylko zajęcia grupowe } \\
\text { rewalidacyjne codzien- } \\
\text { nie, a potem praca zdalna } \\
\text { w domu; } \\
\text { Dwie grupy, w których są } \\
\text { osoby leżące, jeszcze nie } \\
\text { wracają na zajęcia. }\end{array}$ \\
\hline $\begin{array}{l}\text { Zajęcia kulinarne, z zakresu } \\
\text { stolarstwa oraz muzyczne } \\
\text { (tańce i śpiewy). }\end{array}$ & $\begin{array}{l}\text { Zajęcia w „formie okrojonej” } \\
\text { realizowane w domu, przy } \\
\text { pomocy rodzica. }\end{array}$ & Częściowo w formie zdalnej. \\
\hline
\end{tabular}


Przed pandemią
W czasie pandemii wyłącznie edukacja zdalna

(12.03-17.05)
Powrót zajęć RW w ośrodku (od 18 maja 2020)
Terapie specjalistyczne (takie jak fizjoterapia, terapia logopedyczna czy terapia integracji sensorycznej) w osobnej sali, indywidualnie;

Możliwość dodatkowej rehabilitacji poza ośrodkiem (np. w domu, w szpitalu czy w ośrodku rehabilitacyjnym).
Specjaliści wysyłają rodzicom linki do materiałów, które można obejrzeć albo odsłuchać; nagrywanie też własnych filmików; Brak możliwości dodatkowej rehabilitacji poza działaniami ośrodka.
Stopniowe uruchamianie zajęć specjalistycznych $\mathrm{w}$ formie indywidualnej (w pierwszych dniach w formie grupowej); Możliwość dodatkowej rehabilitacji poza ośrodkiem.

Trening umiejętności

Brak takich możliwości.

Brak takich możliwości. społecznych (wychodzenie na zewnątrz, np. do sklepu, do kawiarni, na zewnętrzną siłownię).

\section{Zajęcia dodatkowe o charakterze cyklicznym (prowadzone przez osoby spoza ośrodka), m.in. teatr, zajęcia biblioteczne (wspólne czytanie i opowiadanie); doświadczenia chemiczne; Dogoterapia.}

Obchodzenie świąt narodowych, uroczyste spotkania, ubieranie się na galowo, odśpiewywanie hymnu narodowego (nagrywanie uroczystości i umieszczenie ich na stronie ośrodka).

Realizacja tematu symboli narodowych poprzez powieszenie w domu flagi/lub narysowanie, wyklejenie jej; Akcja, że każdy z podopiecznych pokazuje się na telefonie, a potem zrobienie wspólnego filmu i umieszczenie go na stronie ośrodka.

Formy kontaktu z pod-
opiecznym: kontakt
osobisty/ bezpośredni m.in.
praca z ciałem i pobudzanie
wszystkich zmysłów.

Formy kontaktu z podopiecznym: kontakt osobisty/ bezpośredni m.in. wszystkich zmysłów.
Przesyłanie zdjęć przez rodziców $\mathrm{z}$ wykonanymi zadaniami;

Włączenie nowych technologii, takich jak: Smartfony/ Messenger/Zoom.
Praca każdy tylko w swojej grupie (nie wspólne inicjatywy).

\author{
Zajęcia realizowane równo- \\ legle w dwóch formach (RW \\ na miejscu w ośrodku oraz \\ nauczanie zdalne - zajęcia \\ edukacyjne).
}


W czasie pandemii -

Przed pandemią wyłącznie edukacja zdalna

(12.03-17.05)
Powrót zajęć RW w ośrodku (od 18 maja 2020)
Zajęcia o charakterze praktycznym, poprzez doświadczanie (np. gotowanie, sadzenie roślin, szlifowanie drewna).
Przesyłanie rodzicom szczegółowych opisów wykonania danego zadania (krok po kroku) oraz materiałów do wydrukowania; rodzice zwrotnie wysyłają zdjęcia wykonanych prac oraz filmiki.
Zajęcia o charakterze praktycznym w ośrodku, dodatkowo, w ramach edukacji zdalnej: wysyłanie materiałów mailowo/lub przygotowywanie materiałów w ośrodku i wkładanie ich do plecaka podopiecznych.

Współpraca między specjalistami w formie konsultacji telefonicznych.
W grupie osób $\mathrm{z}$ autyzmem zajęcia ze specjalistą (pracującym metodą behawioralną, m.in. układanie planu dnia, metoda małych kroków); Obserwacja nieuczestnicząca.
Pojawienie się lub nasilenie się zachowań agresywnych i autoagresywnych;

Regres rozwojowy;

Konsultacje specjalistyczne $\mathrm{w}$ formie rozmów telefoniczny wychowawcy ze specjalistami.
Kontakt $\mathrm{z}$ rodzicami: sporadyczny, cykliczny (wywiadówki) natomiast z podopiecznymi bliski i częsty.
Częsty kontakt telefoniczny (kilka razy w tygodniu) prowadzenie wideokonferencji (1-2 razy w tygodniu), gdy osoby wyżej funkcjonujące (w innym przypadku przede wszystkim rozmowy telefoniczne).

\begin{tabular}{|c|c|c|}
\hline $\begin{array}{l}\text { Wsparcie psychologiczne } \\
\text { (rzadsze rozmowy niż } \\
\text { w czasie pandemii), wyzna- } \\
\text { czone dni i godziny. }\end{array}$ & $\begin{array}{l}\text { Stały kontakt rodziców } \\
\text { z psychologiem, dzięki } \\
\text { wideokonferencjom oraz } \\
\text { rozmowom telefonicznym } \\
\text { (w wyznaczonych godzinach, } \\
\text { od godziny 8:oo). }\end{array}$ & $\begin{array}{l}\text { Nadal stałe wsparcie } \\
\text { psychologiczne, w szczegól- } \\
\text { ności dla rodziców, których } \\
\text { dzieci jeszcze nie wróciły do } \\
\text { ośrodka. }\end{array}$ \\
\hline $\begin{array}{l}\text { Rady pedagogiczne oraz } \\
\text { zebrania zespołu cykliczne, } \\
\text { na miejscu. }\end{array}$ & $\begin{array}{l}\text { Regularne cotygodniowe ze- } \\
\text { brania (omawianie bieżących } \\
\text { spraw) i rady pedagogiczne } \\
\text { w formie wideokonferencji }\end{array}$ & $\begin{array}{l}\text { Rady pedagogiczne oraz } \\
\text { zebrania zespołu cykliczne, } \\
\text { na miejscu; } \\
\text { Dodatkowo szkolenie BHP. }\end{array}$ \\
\hline $\begin{array}{l}\text { 2-miesięczna przerwa wa- } \\
\text { kacyjna w funkcjonowaniu } \\
\text { ośrodka (lipiec - sierpień). }\end{array}$ & - & $\begin{array}{l}\text { Nowość: } \\
\text { w lipcu dyżury opiekuńcze } \\
\text { w ośrodku. }\end{array}$ \\
\hline
\end{tabular}

Nadal częsty kontakt telefoniczny z rodzicami.

Źródło: opracowanie własne na podstawie informacji uzyskanych podczas wywiadów.

\section{Kilka refleksji na zakończenie}

Wyjątkowy czas, w jakim się znaleźliśmy - czas pandemii, odsłonił istniejące możliwości i ograniczenia związane z budowaniem w Polsce oferty edukacyj- 
nej i terapeutycznej, dostosowanej do potrzeb osób z niepełnosprawnością. Wprowadzenie obowiązkowego nauczania na odległość spowodowało, iż znaczna liczba uczestników zajęć rewalidacyjnych i specjalistycznych została pozbawiona wielu ważnych doświadczeń o charakterze rozwojowym. Dodatkowo, poważnym zagrożeniem w procesie wdrażania edukacji zdalnej w Polsce jest wykluczenie cyfrowe, gdyż zajęcia online są potencjalnie wykluczające. „Brak odpowiednich metodologii uczenia zdalnego oraz brak przeszkolenia nauczycieli oznacza, że takie nauczanie może być mało efektywne lub wykluczające uczniów o specjalnych potrzebach oraz z niepełnosprawnościami. Równie ważne co nauczanie jest utrzymanie kontaktu" (Tarkowski z zesp., 2020, s. 8-9), stąd istotną rolę upatruje się w działaniach online o charakterze wychowawczym, wzmacniającym dobre relacje między wszystkimi uczestnikami procesu edukacyjnego i terapeutycznego. Współczesna edukacja powinna więc być oparta na modelu pracy nastawionym na budowanie relacji, uwzględniającym ścisłą współpracę między nauczycielami, specjalistami, uczniami i ich rodzicami.

W książce pod redakcją E. Domagały-Zyśk Zdalne uczenie się i nauczanie a specjalne potrzeby edukacyjne. $Z$ doświadczeń pandemii Covid-19 została wyeksponowana ważna rola rodziców w edukacji i terapii zdalnej. Nauczyciele i specjaliści znajdą $\mathrm{w}$ tej książce cenne podpowiedzi dotyczące procesu nauczania uczniów z różnymi niepełnosprawnościami (m.in. $\mathrm{z}$ dysfunkcją słuchu, z niepełnosprawnością ruchową i intelektualną oraz z zaburzeniami mowy i języka). Poszczególne rozdziały zawierają prawne i organizacyjne aspekty edukacji zdalnej, szczególnie w kontekście zapobiegania wykluczeniu cyfrowemu oraz dostosowania narzędzi technologicznych i metod pracy do potrzeb różnych grup odbiorców.

Jedną z dróg naprawczych obecnej sytuacji powinny stanowić zmiany oddolne dokonujące się $\mathrm{w}$ relacjach terapeuty $\mathrm{z}$ rodziną dziecka $\mathrm{z}$ niepełnosprawnością. Pandemia uwidoczniła konieczność rozbudowania sieci wsparcia oraz różnych form pomocy psychologiczno-pedagogicznej dla tych rodzin. Jednym z wartościowych rozwiązań jest organizacja tzw. opieki wytchnieniowej ${ }^{8}$. Druga droga, prowadząca do szeroko rozumianej transformacji, powinna obejmować zmiany odgórne ${ }^{9}$, nastawione na globalne przekształcenie systemu edukacji i rehabilitacji.

Na poziomie kraju należy wypracować rekomendowane modele, z których mogą skorzystać szkoły. Model taki powinien określać miks edukacyjny zapewniający

8 Więcej na ten temat w Raporcie Fundacji Imago (Raport..., 2019).

9 Więcej na ten temat w tekście: M. Pachowicz (2013). 
edukację zdalną, która jest efektywna i niewykluczająca. Jednocześnie należy szkołom pozostawić możliwość dostosowania przyjętego modelu do potrzeb ich uczniów i nauczycieli. Zestandaryzowane powinny być natomiast formy wsparcia. Należy wspierać wymianę doświadczeń i dobrych praktyk między nauczycielami i uczniami (Tarkowski z zesp., 2020, s. 9).

Edukacja zdalna to duże wyzwanie dla wszystkich nauczycieli i pedagogów, jednak specyfika pracy z osobami z niepełnosprawnością powoduje, że staje się ona szczególnie trudna z wielu powodów. Pedagodzy specjalni oraz inni specjaliści stracili w czasie pandemii możliwość bezpośrednich form kontaktu z podopiecznymi, które stanowiły do tej pory podstawę ich działań terapeutycznych. W szczególności zajęcia z osobami ze sprzężoną i głębszą niepełnoprawnością opierają się na praktycznych działaniach poprzez doświadczanie, pobudzanie wszystkich zmysłów i pracę z ciałem. Ograniczone możliwości w tym zakresie oraz niemożność uczęszczania na zajęcia specjalistyczne/rehabilitacyjne spowodowała u wielu dzieci z niepełnosprawnością regres, deprywację sensoryczną, a u niektórych pojawiły się lub nasiliły zachowanie agresywne i autoagresywne. W szczególnie trudnej sytuacji zostali postawieni rodzice tych dzieci. Dodatkowym obciążeniem dla wielu z nich jest niekorzystna sytuacja ekonomiczna (wynikająca m.in. z dużych kosztów, jakie ponoszą ci rodzice na rehabilitację i różne terapie), a co za tym idzie ograniczony dostęp do nowych technologii. Dlatego też działania specjalistyczne wczasie pandemii skoncentrowane zostały na budowaniu systemu wsparcia dla rodziców, którzy stali się niezbędnym ogniwem działań edukacyjnych i rewalidacyjnych.

\section{BIBLIOGRAFIA}

Domagała-Zyśk, E. (red.), (2020). Zdalne uczenie się i nauczanie a specjalne potrzeby edukacyjne. $Z$ doświadczeń pandemii Covid-19. Lublin: Wydawnictwo Episteme.

Flick, U. (2011). Jakość w badaniach jakościowych. Warszawa: PWN.

Flick, U. (2012). Projektowanie badania jakościowego. Warszawa: PWN.

Gajdzica, Z. (red.). (2013). Człowiek z niepetnosprawnością w rezerwacie przestrzeni publicznej. Kraków: Impuls.

Humphrey, N. i Hebron, J. (2014). Bullying of children and adolescents with autism spectrum conditions: A 'state of the field' review. International Journal of Inclusive Education, No $19(8), 1-8$. DOI: $10.1080 / 13603116.2014 .981602$

Kułaga, A. (2020). Zdalne nauczanie uczniów z niepełnosprawnością intelektualną w stopniu umiarkowanym. W: E. Domagała-Zyśk (red.), Zdalne uczenie się i nauczanie a specjalne potrzeby edukacyjne. Z doświadczeń pandemii Covid-19 (Roz. 4, s. 83-93). Lublin: Wydawnictwo Episteme.

Längle, A. (2019). Śladami sensu. Jakie pytania stawia nam życie? Warszawa: Imprint Media.

Pachowicz, M. (2013). Próba wyjścia z rezerwatu. O paradoksach ukrytych w edukacji i rewalidacji osób niepełnosprawnych. W: Z. Gajdzica (red.), Człowiek z niepetnosprawnościq $w$ rezerwacie przestrzeni publicznej (s. 327-346). Kraków: Impuls. 
Plichta, P. (2020). Różne konteksty nierówności cyfrowych a wyzwania dla zdalnej edukacji - propozycje rozwiązań. W: J. Pyżalski (red.), Edukacja w czasach pandemii wirusa COVID19. $Z$ dystansem o tym, co robimy obecnie jako nauczyciele. Warszawa: EduAkcja.

Podsiadło-Dacewicz, I. (red.). (2020). Budowanie relacji. Materiały do pracy zdalnej z uczennicami i uczniami. Warszawa: Wyd. Warszawskie Centrum Innowacji Edukacyjno-Społecznych i Szkoleń. Pozyskano z: https://www.wcies.edu.pl/media/system/pdf/prawa/Antydyskryminacja_z-zdalny_online.pdf

Poleszak, W. i Pyżalski, J. (2020). Relacje przede wszystkim - nawet jeśli obecnie jedynie zapośredniczone. W: J. Pyżalski (red.), Edukacja w czasach pandemii wirusa COVID-19. $Z$ dystansem o tym, co robimy obecnie jako nauczyciele. Warszawa: EduAkcja.

Pyżalski, J. (red.). (2020). Edukacja w czasach pandemii wirusa COVID-19. Z dystansem o tym, co robimy obecnie jako nauczyciele. Warszawa: EduAkcja.

Pyżalski, J. (2020). Co jest obecnie ważne, a co mniej w działaniach szkół i nauczycieli?. W: J. Pyżalski (red.), Edukacja w czasach pandemii wirusa COVID-19. Z dystansem o tym, co robimy obecnie jako nauczyciele. Warszawa: EduAkcja.

Tarkowski, A. z zesp. (2020). Problem wykluczenia cyfrowego w edukacji zdalnej. Warszawa: Fundacja Centrum Cyfrowe. Pozyskano z: https://centrumcyfrowe.pl/wp-content/uploads/sites/16/2020/o3/Problem-wykluczenia-cyfrowego-w-edukacji-zdalnej-2020.pdf

Raport Fundacji Imago „OPIEKA WYTCHNIENIOWA - DOBRE PRAKTYKI Z KRAJU I ZAGRANICY”. Raport z analizy efektów testowanego rozwiązania w ramach projektu: „Usługi przerwy regeneracyjnej dla opiekunów niepełnosprawnych osób zależnych”. Wrocław, 2019. Pozyskano z: http://fundacjaimago.pl/wp-content/uploads/Raport_final. pdf

\section{SUMMARY}

\section{Education and therapy of people with disabilities during the COVID-19 pandemic on the example of the Educational, Rehabilitative and Pedagogical Centre}

The time of closed schools and educational institutions during the COVID-19 pandemic has exposed existing social inequalities in terms of access to educational and therapeutic services in Poland. The introduction of compulsory remote teaching has made it difficult for a significant number of students (from poor areas or homes) to access education due to the limited possibilities of using new technologies and the internet. People with special developmental and educational needs and their families are in particularly difficult situations. Many of these families are disadvantaged due to the high costs they incur for rehabilitation and various therapies.

This article describes special education and remote therapy during the COVID-19 pandemic and after relaunching revalidation and education classes in May 2020. The perspective of teachers, therapists and specialists working at the Educational, Rehabilitative and Pedagogical Centre was emphasized. The article presents the data collected on the basis of interview conducted during the closure of the Centre and after the relaunching of specialized classes. Therefore, qualitative research methods were used that allowed to outline the micro perspective.

KEY WORDS: pandemic, special education, remote (distance) learning, a child with special developmental and educational needs, therapy, disability, psychological and pedagogical help, rehabilitation 